\title{
Degradation of Chlorogenic Acid by the Enzymes from the Timothy Leaf Spot Fungus, Cladosporium phlei
}

\author{
Yōsuke Mino*, Ryutaro SAKAI* and Akira TAMURA* \\ 美瀑羊辅*・酒井隆太郎*・田村 聡*：チモシー斑点病菌 Cladosporium phlei \\ から調製した醭素によるクロロゲン酸の分解
}

\begin{abstract}
Chlorogenic acid was hydrolyzed to caffeic and quinic acids, and caffeic acid was further decarboxylated to 3,4-dihydroxystyrene by the enzymes prepared from the timothy leaf spot fungus, Cladosporium phlei. Neither chlorogenic acid hydrolase nor caffeic acid decarboxylase was inducible.
\end{abstract}

(Received May 6, 1981)

\section{Introduction}

Phenolic compounds have been reported to accumulate in the vicinity of the plant tissues infected with phytopathogens ${ }^{4}$, together with the increases in polyphenol oxidase and peroxidase activities ${ }^{6}$. Among them chlorogenic and caffeic acids were shown to be main phenolic compounds in black-rotted sweet potato ${ }^{7,8)}$. Kuć et al. ${ }^{1,2)}$ also reported the accumulation of these acids in potato tuber infected with Helmithosporium carbonum. These phenomena are generally explained in terms of the resistance shown by plants against plant pathogens ${ }^{6}$. However, little is known about the decomposition of phenolic acids by phytopathogens. This paper deals with the degradation of chlorogenic and caffeic acids by timothy leaf spot fungus, Cladosporium phlei.

\section{Materials and Methods}

Fungal culture. A pathogenic isolate of Cladosporium phlei (Gregory) de Vries was used. The stock culture was maintained on the medium of potato-dextrose slant at $25 \mathrm{C}$ in the dark for a month. From this stock culture a loopful of the fungus was inoculated into a $500 \mathrm{ml}$ Erlenmeyer flask containing $250 \mathrm{ml}$ of potato extract medium containing $2 \%$ dextrose and cultured without shaking at $20 \mathrm{C}$ for 20 days. The fungal culture was also conducted using a synthetic medium under the same condition as mentioned above. The medium consisted of dextrose $10 \mathrm{~g}, \mathrm{NH}_{4} \mathrm{NO}_{3} 2 \mathrm{~g}, \mathrm{KH}_{2} \mathrm{PO}_{4} 2 \mathrm{~g}$, $\mathrm{Na}_{2} \mathrm{CO}_{3} 1.2 \mathrm{~g}, \mathrm{MgSO}_{4} \cdot 7 \mathrm{H}_{2} \mathrm{O} 0.5 \mathrm{~g}, \mathrm{FeSO}_{4} \cdot 7 \mathrm{H}_{2} \mathrm{O} 0.2 \mathrm{mg}, \mathrm{ZnSO}_{4} \cdot 7 \mathrm{H}_{2} \mathrm{O} 0.2 \mathrm{mg}, \mathrm{MnSO}_{4} \cdot 5 \mathrm{H}_{2} \mathrm{O}$ $0.2 \mathrm{mg}$, thiamine $0.1 \mathrm{mg}$ and pyridoxine $0.5 \mathrm{mg}$ in 1 liter water.

* Obihiro University of Agriculture and Veterinary Medicine, Hokkaido 080, Japan 帯広音産大学 䍗境植物学研究室 
Enzyme preparation. The washed fungus (fr. wt. $25 \mathrm{~g}$ ) cultured in potato-dextrose medium, was homogenized in $80 \mathrm{ml}$ of phosphate buffer $(\mathrm{M} / 15, \mathrm{pH} 6.8)$ with $20 \mathrm{~g}$ of quartz sand and $10 \mathrm{~g}$ of Polyclar AT using a chilled mortar. The homogenate was centrifuged at $13,000 \times \mathrm{g}$ at $0 \mathrm{C}$ for $10 \mathrm{~min}$. The supernatant was used as enzyme solution without further purification.

Isolation and identification of decomposition products. Twenty $\mathrm{ml}$ of the enzyme solution containing $5 \mathrm{mg}$ of chlorogenic acid were incubated at $30 \mathrm{C}$ for $2 \mathrm{hr}$. After removing proteins by the addition of $2.5 \mathrm{ml}$ of each $5 \% \mathrm{ZnSO}_{4}$ and $4.8 \% \mathrm{Ba}(\mathrm{OH})_{2}$ solution, the supernatant obtained by centrifugation was acidified to $\mathrm{pH} 3.0$ with 1N $\mathrm{HCl}$, followed by extraction with an equal volume of ethlyether three times. The combined organic layer was dehydrated with anhydrous sodium sulfate and evaporated to dryness at $30 \mathrm{C}$ using a rotary evaporator. The residue was dissolved in $1 \mathrm{ml}$ of methanol as a sample for ascending paper chromatography. Solvents used were butanol/acetic acid/water (BAW) (4:1:2.5), $2 \%$ acetic acid solution (A) and formic acid/sodium formate/water (FSW) $(1: 10: 200)$. The degradation products on paper chromatograms were detected with $2 \%$ ferric chloride solution and ethanol containing $0.6 \%$ bromophenol blue.

Isolation of two degradation products ( $A$ and $C$ ) from chlorogenic acid was carried out using the solvent system (FSW). Each band on paper chromatogram was eluted with methanol. The isolated products were analyzed by ultraviolet (UV) and infrared (IR) spectrometries. On the other hand, the water layer adjusted to $\mathrm{pH} 6.0$ was also evaporated to dryness at $80 \mathrm{C}$ in vacuo. The residue was dissolved in $10 \mathrm{ml}$ of ethanol, followed by filtration. Ethanol was condensed to about $1 \mathrm{ml}$ under reduced pressure and then filtered. The filtrate containing product $B$ was also subjected to paper chromatography.

\section{Results}

\section{Detection of decomposition products from chlorogenic acid by paper chromatography}

As shown in Table 1, main three spots (product A, B and C) were detected on paper

Table 1. Rf values of degradation products from chlorogenic acid

\begin{tabular}{lccc}
\hline \multirow{2}{*}{ Substance } & \multicolumn{3}{c}{ Solvent system } \\
\cline { 2 - 4 } & BAW & $\mathrm{A}$ & FSW \\
\hline Product A & 0.92 & 0.19 & 0.32 \\
Caffeic acid & 0.92 & 0.21 & 0.30 \\
Product B & 0.34 & 0.82 & 0.90 \\
Quinic acid & 0.33 & 0.82 & 0.91 \\
Product C & 0.81 & 0.54 & 0.54 \\
3, 4-Dihydroxystyrene & 0.81 & 0.56 & 0.51 \\
\hline
\end{tabular}

Caffeic acid and 3,4-dihyroxystyrene were detected with $\mathrm{FeCl}_{3}$ solution and quinic acid with bromophenol blue solution. 


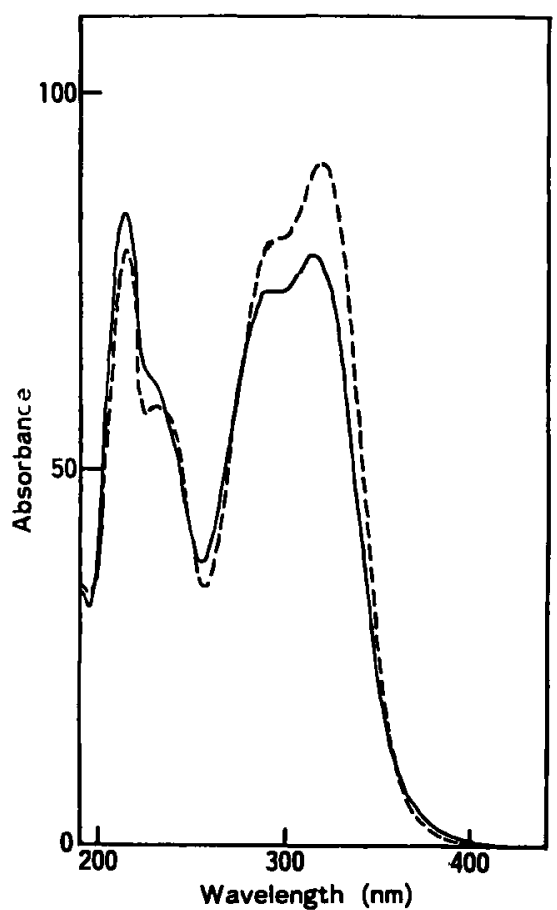

Fig. 1. UV spectra of a degradation product A from chlorogenic acid and authentic caffeic acid. Solid and broken lines indicate product $A$ and authentic caffeic acid, respectively. chromatograms, product $\mathrm{A}, \mathrm{B}$ and $\mathrm{C}$ showing $\mathrm{Rf}$ values similar to those of authentic caffeic acid, quinic acid and 3,4-dihydroxystyrene, respectively.

\section{Identification of product $A$ and $C$}

From the comparison of their UV and IR spectra, product $A$ was identified to be caffeic acid (Figs. 1 and 2). Product $C$ was also formed from caffeic acid instead of chlorogenic acid by the enzyme solution. As shown in Figs. 3 and 4, product $\mathrm{C}$ was identified to be 3,4-dihydroxystyrene from the similarity between their UV and IR spectra, respectively. These results lead to a conclusion that chlorogenic acid is first hydrolyzed to caffeic and quinic acids, followed by decarboxylation of caffeic acid to 3,4-dihydroxystyrene. The same result was obtained using the enzymes from C. phlei cultured in the synthetic medium as described above (data are not detailed here). This suggests that the enzymes concerned were not inducible. Neither chlorogenic nor caffeic acid was decomposed by the enzyme solution heated at $100 \mathrm{C}$ for $5 \mathrm{~min}$ irrespective of the media used.

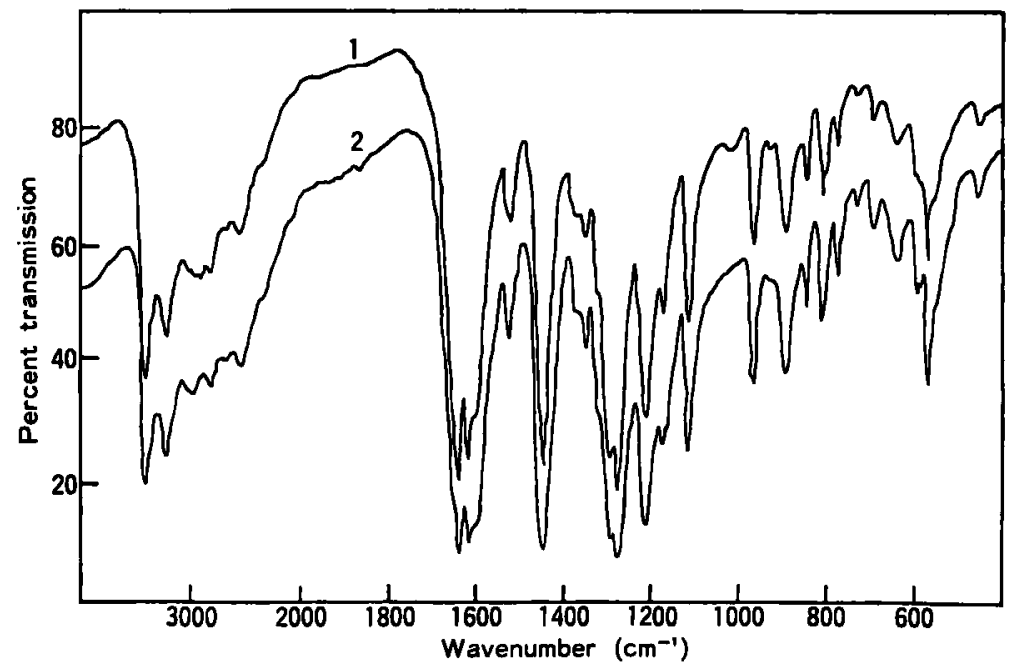

Fig. 2. IR spectra of a degradation product $A$ from chlorogenic acid and authentic caffeic acid. Curve 1 stands for product $A$ and curve 2 for authentic caffeic acid. 


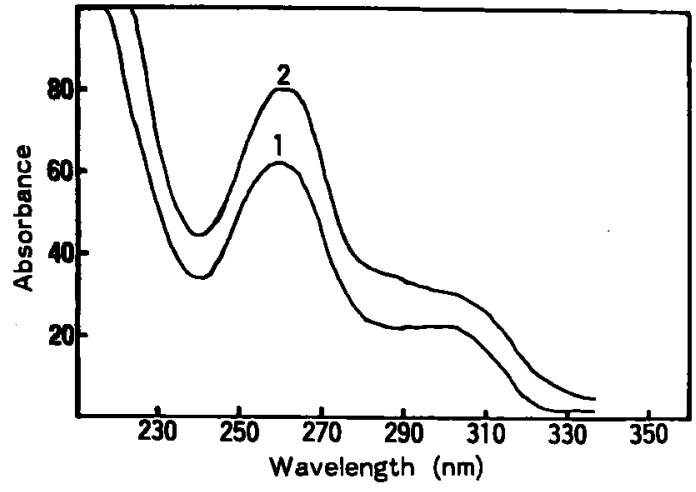

Fig. 3. UV spectra of a degradation product $C$ from caffeic acid and authentic 3, 4-dihydroxystyrene. Curve 1 stands for product $C$ and curve 2 for authentic 3,4-dihydroxystyrene.

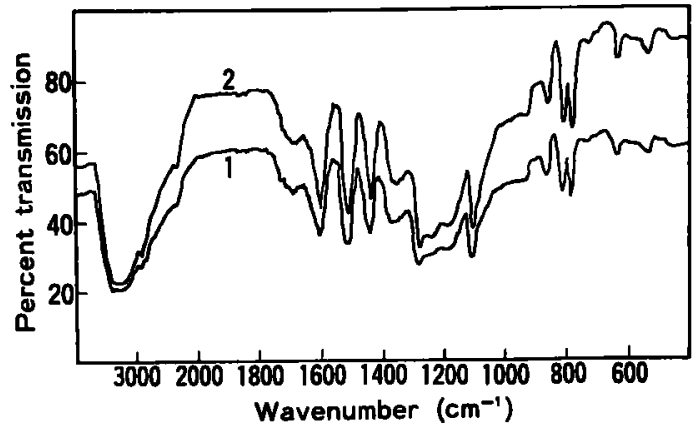

Fig. 4. IR spectra of a degradation product C from caffeic acid and authentic 3, 4-dihydroxystyrene. Curve 1 stands for product $C$ and curve 2 for authentic 3,4-dihydroxystyrene.

\section{Discussion}

The roles of phenolic compounds such as chlorogenic and caffeic acids have been explained mainly in relation to the resistance of plants against phytopathogens ${ }^{6}$. In this study Cladosporium phlei was shown to decompose these acids (Figs. 1-4), suggesting that the function of phenolic compounds in the infected region should be also studied in terms of phytopathogens.

Mino and Harada ${ }^{3)}$ demonstrated the occurrence of chlorogenic and caffeic acids in the leaves of timothy (Phleum pratense). On the other hand, Shimanuki and Sato ${ }^{5)}$ have recently reported that polyphenols were accumulated around the leaf spots on timothy leaves by the infection of $C$. phlei. It remains, however, uncertain whether the enzymes detected by the in vitro experiments play some roles in the degradation of phenolic compounds, leading to the nullification of their toxicity against this fungus. It will be therefore essential to elucidate the in vivo functions of these enzymes from the viewpoint of host-parasite interaction.

We wish to express our thanks to Mr. T. Shimanuki for his kind providing Cladosporium phlei.

\section{Literature cited}

1. Kuć, J. (1957). Phytopathology $47:$ 676-680.

2. Kuć, J., Henze, R. E., Ullstrup, A. J. and Quackenbush, F. W. (1956). J. Am. Chem. Soc. 78: 3123-3125.

3. Mino, Y. and Harada, T. (1974). J. Japan. Grassl. Sci. 20 : 193-198.

4. Sakai, R., Tomiyama, K., Ishizaka, N. and Sato, N. (1967). Ann. Phytopath. Soc. Japan 33 : 216-222.

5. Shimanuki, T. and Sato, T. (1981). Ibid. $47:$ 380-381.

6. Tomiyama, K. (1979). Infection Physiology of Plants (In Japanese). UP Biology Series, Tokyo University Press, Tokyo. pp. 57-64.

7. Uritani, I. (1953). J. Agr. Soc. Japan $27:$ 165-168.

8. Uritani, I. (1953). Ibid. 27 : 29-33. 
和 文 摘 要

チモシー斑点病菌 Cladosporium phlei から調製した酵素による クロロゲン酸の分解

美濃羊輔・酒井隆太郎・田村 聡

チモシー斑点病菌 Cladosporium phlei 上り調製した醥に上り，クロロゲン酸はコーヒー酸とキナ酸に加 水分解され，さらにコーヒ一酸は脱炭酸されて 3,4-dihydroxystyrene となった。これらクロロゲン酸加水 分解醅素およびューヒー酸脱炭酸酵素は誘導酵素ではなかった。 